\title{
The Effectiveness of Using Comic Strips to Increase Students' Reading Comprehension for The Eight Grade of SMPN 1 Pundong
}

\author{
Zul Aini Rengur \\ Graduate School \\ Universitas Negeri Yogyakarta \\ Yogyakarta, Indonesia \\ ainy_syifa@yahoo.com
}

\author{
Sugirin \\ Graduate School \\ Universitas Negeri Yogyakarta \\ Yogyakarta, Indonesia \\ sugirin@uny.ac.id
}

\begin{abstract}
This research was aimed to find out whether the use of comic strip was more effective than the use of conventional media in increasing students' reading comprehension. This research was quasi-experimental research which involved two groups, there were the experimental group and the control group. The samples were three classes of the eight grade students of SMPN 1 Pundong, Bantul, Yogyakarta. The variables of the research were comic strip as the independent variable, while the dependent variable was students' reading comprehension. The data collection used a pre-test and post-test. Data analysis was used ANCOVA. The result of the research shows that the use of comic strip was more effective than the use of conventional media in students' reading comprehension by the results of LSD test with a mean difference of 0.265 and a significance of $p 0.00$ was lower than 0.05 .
\end{abstract}

\section{Keywords: Comic strips, reading comprehension.}

\section{INTRODUCTION}

Reading plays an important role in the English learning process. In many second or foreign language teaching situations, reading receives a special focus. Reading texts provide opportunities to study language such as vocabulary, grammar, punctuation, and the way of constructing sentences, paragraphs, and texts. Reading is one of the complex skills. Reading needs recognition and explanation processes which require the readers' knowledge about the language structure used in the text and their knowledge about the given topic [1-3]. Relevant background knowledge is an important factor in reading comprehension than grammatical complexity. This kind of complexity often makes it difficult for students to comprehend reading texts.

To avoid the complexity above, students need to comprehend the contents and the topics of the text. Students usually read without comprehending the text. Meanwhile, reading activities need comprehension to know the contents of the text. Since, without comprehending the contents of the text, students cannot achieve the purposes of reading. It is emphasized by Grabe and Stoller that reading for general comprehension is the ability to understand information in a text and interpret it appropriately [4].

Reading activities are focused to improve students' comprehension in reading the passage. Despite reading plays a main role in teaching process and it can help the students in many aspects of their life, but they still face many problems in reading comprehension. Gunning has investigated the problems of reading comprehension of English foreign language learners are the lack of vocabularies, limited background knowledge of the students, the text given to the students was not appropriate with the level competence [5]. Therefore, it can be concluded that students' reading problems are about lack of vocabularies, the limitation of students' background knowledge, and the appropriate materials are needed. Reading comprehension refers to get the meaning and understanding the text and it involves the reader, the text, and the interaction between the reader and the text. Reading comprehends about the written text and composed of two related processes.

Teachers are the fundamental role in the teaching and learning process, and teachers should stimulate students in learning process. Meanwhile, teachers often used textbook in the classroom without applied some visual media that can improve students' interest. Visual media can be used to help teachers deliver their material easily. Considering the effectiveness of using visual media in teaching and learning process, this research used comic strips as teaching and learning media which can improve students' reading comprehension. Comic strips play an essential role to support the teaching and learning process. This media has been effective in increasing students' reading comprehension. Rokhayati and Utari have investigated the use of comic strip as an English teaching media for Junior High School students was effective. The visualization through pictures and text can support the sharing of the materials from the teacher to students. The teaching and learning process called successful if the result or the output is success [6]. Thus, comic strips as the media in teaching students' reading comprehension should be implemented in the English classroom.

Comic strips create massages through story line and images. Comic strip have some benefits such as; assisting students comprehending the contents of text, helping the students to improve their ideas, increasing the students' interest in reading. Carry claims that in comics, readability measures are determined not only 
on words alone, but also on pictures. Here, pictures support the words to make the written text becomes more comprehensible [7]. It means comic strip is a kind of comic which is made by putting the pictures and the words in the right order.

Comics are usually funny, applying them to methodological purposes will have the same effect as using games in teaching English it brings a good atmosphere into the class. Comic strip is not only amusing and interest L2 students; there are plenty of other reasons to use them in education. As Liu states that EFL and ESL teachers often give students reading material accompanied by visuals such as pictures, cartoons, or comic strip to make reading more enjoyable and comprehensible [8-9].

Meanwhile, Mahir et al claim that comic strip spark laughter or amusement that will have a great influence to attract students' attention in learning activities [10] It has been used excessively as one of the medias to entertain students' learning session. One way to arouse students' interest in reading activity can be achieved by giving something extraordinary into the language class to cope the boredom and the complex language. Therefore, Roozafzai argues that comic strip is more interest-getting and enjoyable which draw readers' attention more considerably and stir their imagination more efficiently [11]. It is also stated by William that using comic in second language classroom can guide students in hypothesizing about the cartoons' language, raise awareness of pragmatics, and emphasize language's underlying regularity [12]. The use of visual media will help students easier in learning process and make them more interesting in reading activity. Considering the explanations above, it is clearly stated that comic strip is a sequence of pictures which has the meaningful message conveyed in some words related to the theme of the graphic. This research was aimed to find out whether the use of comic strip was more effective than the use of conventional media in increasing students' reading comprehension.

\section{MATERIAL AND METHODOLOGY}

The type of this research was the quantitative research which used a quasi-experimental design. The researcher used this type of the research because of the experimental subject cannot be fully controlled even it has been maximized control. This study proved the effectiveness of using comic strip as media in teaching reading comprehension. In addition, this study aimed to determine the effective media between students who were taught using comic strips and conventional media.

There were two groups related to this research: the experimental group and the control group. The experimental group was the group using the treatment (using comic strips), and the control group was a group without using comic strips. The researcher gave the pretest and the post-test to experimental group and the control group. After conducting the pre-test, the researcher conducted the treatment only to the experimental groups. In the end of the teaching process, the researcher conducted the post-test to find out the effective media. The table of the research design is shown below.

\begin{tabular}{|c|c|c|c|}
\hline Group & Pre-test & Treatment & Post-test \\
\hline Experiment & O1 & $\mathrm{X} 1$ & $\mathrm{O} 2$ \\
\hline Control & $\mathrm{O} 3$ & - & $\mathrm{O} 4$ \\
\hline
\end{tabular}

Notes:

O1: Pre-test for experimental group

$\mathrm{X} 1$ : The treatment by using comic strips

O2: Post-test for experimental group

O3: Pre-test for control group

O4: Post-test for control group

In this research, the researcher used content validity. It was used to know the content of the test which was appropriate with standard competence and basic competence based on the school curriculum. Content validity explains whether all the items of the test were suitable with the relevant materials or not. The researcher organized the test instrument based on the syllabus of reading skill for Junior high school. The research also validated the instrument by using construct validity and it has been measured by the expert judgment. Meanwhile, the researcher used ITEMAN 4.00 version program to measure the reliability of instrument. The result of reliability coefficient of the pre-test was 0.961 and the post-test was 0.936 . Meanwhile, the reliability coefficient is at least 0.7. Therefore, the pre-test and the post-test were reliable as the research instrument.

\section{RESULT AND DISCUSSION}

\section{A. Result}

The result data of the pretest and the posttest from experimental and control groups are presented in table below.

TABLE II. THE RESULT OF PRETEST AND POSTTEST FOR THE EXPERIMENTAL AND CONTROL GROUP

\begin{tabular}{|c|c|c|c|c|}
\hline \multirow{2}{*}{} & \multicolumn{2}{|c|}{$\begin{array}{c}\text { Experimental } \\
\text { Group }\end{array}$} & \multicolumn{2}{c|}{ Control Group } \\
\cline { 2 - 5 } & Pretest & Posttest & Pretest & Posttest \\
\hline Mean & 46.3333 & 74.74 & 36.27 & 53.7 \\
\hline Median & 47 & 75.56 & 39 & 55.56 \\
\hline Maximum & 62 & 88.89 & 70 & 82.22 \\
\hline Minimum & 32 & 55.56 & 12 & 26.67 \\
\hline $\begin{array}{c}\text { Standard } \\
\text { Deviation }\end{array}$ & 8.12121 & 9.07 & 16.41 & 13.42 \\
\hline
\end{tabular}

Based on the Table, it can be seen the result of students reading comprehension before and after conducting the treatment. The pretest result of the experimental group presents that the mean score was 46.33 , the median was 47 , the minimum score was 32 , the maximum score was 62 , and the standard deviation was 8.12. Meanwhile, the posttest result presents that the mean score was 74.74 , the median was 75.56 , the 
minimum score was 55.56 , the maximum score was 88.89 and the standard deviation was 9.07.

The next, it was discussed about the pretest result of the control group presents that the mean score was 36.27 , the median was 39 , the minimum score was 12 , the maximum score was 70 and the standard deviation was 16.41. Meanwhile, the posttest result presents that the mean score was 53.7, the median was 55.56, the minimum score was 26.67 , the maximum score was 82.22, and the standard deviation was 13.42 .

Then, for all the result show that there is significant difference between pretest and posttest. It means there is significant between the groups from the samples, while the experimental group reached the highest enhancement related to students reading comprehension.

\section{B. Discussion}

In this section, the researcher proposed to explain about the results of the research finding. Meanwhile, the objectives of the study were to find out whether the use of comic strips is more effective than the use of conventional media in students' reading comprehension.

Based on the data analysis, it shows that the hypothesis of this research was accepted. The use of comic strips also shows more effective than the use of conventional media. It revealed by the value of mean difference was 0.265 .

The researcher used this media to increase students' reading comprehension. Comic strip was proved effective in teaching students' reading comprehension. On the other hand, the use of comic strips is the most effective media, due to it consists of pictures and story line that make students more interested in reading. The students must understand the story line and the comic strip to create a good text. Comic strip is appropriate and effective as teaching media not only in reading comprehension but also in teaching English vocabulary, because it deserves an easy way to present the English material.

This research has similar results with Merc who investigates the effects of comic strip on reading comprehension of Turkish EFL learners [13]. The result showed that all students who taught using comic strips are better in comprehending the text because it is included visual or the picture in increasing reading comprehension. It showed by the mean score of students using comic strips is $\mathbf{5 2 . 3 8}$ and the mean score of students without using comic strips is 16.75 [13] Therefore, it can be said that there is significant difference between students who were taught using comic strips than the groups without comic strip. The other study was conducted in Argentina by Ravelo who investigated the use of comic strips as a means of teaching history in the EFL class [14]. This study was aimed to know that the use of comic strips can be regarded as a valid resource to teach history in the EFL classroom with CLIL (content language integrated learning) as the methodological framework [14]. Then, the result is presented that comic strips are appropriate and practical genre for facilitating the teaching and learning of history in the CLIL classroom, because the students can understand the meanings through words and images.

Furthermore, there were some students in EFL classroom at Japanese universities have lower abilities, attitudes and motivations in English reading. They are often bored and need dictionaries to look for the meaning of new vocabularies. Hence, Jones gave a new approach by using comic book style graded readers into the extensive reading program [15]. The approach was showed that the students were very enjoy the comic book and had the good motivation in reading English.

\section{CONCLUSION}

Based on the data analysis and the discussion of the finding, it can be concluded that the use of comic strip as media is more effective than the use of conventional media. This indicated by the research finding that the student who were taught using comic strips presented the better result than the students who were taught using conventional media in teaching students reading comprehension. The conclusion is showed that the most effective media is comic strips, because the students who were taught using comic strips presented the better result in students' reading comprehension than conventional media.

\section{ACKNOWLEDGEMENT}

In this occasion, I would like to express my respect and honor to Yogyakarta State University, especially Applied Linguistic Program Study with all the support. For my supervisor, Prof. Sugirin, Ph.D., with his guidance, motivation, advice, suggestions, and correction. I hope that this article would be useful for the readers. However, I realize that this is far from being perfect, so any criticisms, ideas, and suggestions for the improvement of this thesis are greatly appreciated.

\section{REFERENCES}

[1] Richards J. C. and Renanyda W. A., Methodology in Language Teaching, New York: Cambridge University Press, 2002.

[2] Harmer J., How to teach English: An Introduction to The Practice of English Language Teaching, England: Longman, 1998.

[3] Nunan D., Designing Tasks for The Communicative Classroom, Cambridge: Cambridge University Press, 1989.

[4] Grabe W. and Stoller L. F., Teaching and Researching Reading, Longman: An Imprint of Pearson Education, 2002.

[5] Gunning T. G., Assessing and Correcting Reading and Writing Difficulties, Boston: Allyn and Bacon, 2002.

[6] Rokhayati A and Utari, P R A., Language Circle Journal of Language and Literature. :7, 2014, pp. 143-149.

[7] Cary S., Going Graphic: Comics at Work in The Multilingual Classroom, Portsmouth, Nh: Heinemann, 2004.

[8] Csabay N., Using comic strips in language classes English Teaching Forum Magazine, 2006, pp. 24-26. 
[9] Liu J., TESOL Quarterly. :38, 2004, pp. 225-243.

[10] Mahir N. A., Ali R, M., Amin K. M., Journal of Global Business and Social Entrepreneurship (GBSE). :2, 2016, pp. 57-62.

[11] Roozafzai Z. S., I-manager's Journal on English Language Teaching, :2, 2012, pp. 7-15.
[12] Williams N., The comic book as course book: why and how eric, 1995. fulltext/ED390277

[13] Merc A., International Journal on New Trends in Education and Their Implications, :4, 2013 pp. 1309-6249.

[14] Ravelo L. C., Latin American Journal of Content and Language Integrated Learning, :6, 2013, pp. 1-19.

[15] Jones E., Language Education in Asia, :1, 2010, pp. 228-241. 